Treatment of Recurrent Aphthous Stomatitis and Herpes with Levamisole

SIR,-Your leading article on "Recurrent Oral Ulceration" (28 September, p. 757) points out the relevance of cell-mediated immunity in recurrent aphthous stomatitis. A year ago Verhaegen et al. ${ }^{1}$ reported improvement of recurrent aphthous stomatitis on treatment with levamisole, a drug that restores phagocytic function and cutaneous delayed hypersensitivity reactions when they are deficient. ${ }^{2-4}$ Recently Kint and Verlinden ${ }^{5}$ published similar data on the treatment of recurrent herpes infections.

In a collaborative effort with 15 investigators we have further studied the therapeutic and prophylactic effects of levamisole in both conditions. All patients had had lesions at least once a month for more than one year. Levamisole $(150 \mathrm{mg}$ ) was given as the sole treatment for three consecutive days every fortnight.

During the first month of levamisole treatment 25 of 82 patients with aphthous ulcers became free of lesions, in 25 patients the lesions were less severe and the episode was shorter than usual, and in 32 patients the treatment was ineffective. During the second month of treatment the number of responders increased to about $70 \%$ and remained so during the six-month observation period (see table). When treatment was discontinued most responders did not relapse for several months, while eight patients who had not responded to treatment became symptom-free for the first time for an appreciable period. The results in herpes infections were also promising. All but one of 25 patients with recurrent herpes labialis or genitalis responded to therapy. Side effects, mainly gastric intolerance, were seen in approximately $10 \%$ of the patients. They could be overcome by dividing the daily dose into three parts.

Preliminary data indicate that the response to levamisole was not a placebo effect; in four patients in whom a two-month doubleblind placebo period preceeded levamisole treatment the symptoms remained unchanged during that time.

The tentative conclusion from this exploratory study is therefore that levamisole changes the natural course of recurrent aphthous stomatitis and herpes infections. It is reasonable to assume that levamisole in fluences a basic mechanism responsible for the recurrent character of these diseases. This is in contrast to the more symptomatic treatment with topical antibiotics and corticosteroids which suppress possible superinfection, autoimmunity, and inflammation Further double-blind studies must now be designed and the dosage schedule furthe investigated to reach a valid conclusion on the therapeutic value of levamisole. In view of the effect of the drug on cell-mediated immunity, ${ }^{6}$ tumour immunology, ${ }^{7}$ host defence mechanisms, ${ }^{89}$ and phagocytosis ${ }^{2}$ these studies might also shed some light on the immunopathology of recurrent aphthous ulceration.

A detailed report is available on request. -We are, etc.,

J. SYMOENS

Janssen Pharmaceutica,

J. BRUGMANS

Beerse, Belgium

1 Verhaegen, H., De Cree, J., and Brugmans, J., Lancet, 1973. 2, 842

2 Hoebeke, J., and Franchi, G., fournal of the Reticuloendothelial Society, 1973, 14, 317.

New England fournal of Medicine, 1973, 289,
354.,

4 Brugmans, J., et al., Life Sciences, 1973, 13, 1499. Kint, A., and Verlinden, L. New England Joumal of Medicine, 1974, 291, 308.

Churchill, w. H., and David. J. R., New England fournal of Medicine, 1973, 289. 375. Chirigos, M. A., Pearson, J. W.; and Pryor, J.,
Cancer Research, 1973, 33, 2615.

Renoux, G., and Renoux, M., Infection and

9 De Cree. J., et al., Lancet, 1974, 2, 294.

\section{Anastomotic Leakage}

SIR,-In your leading article on this subject (2 November, p. 251) stress is rightly laid upon the importance of an adequate blood supply and reference is made to other details such as suture material, though after a considerable experience of oesophageal anastomosis I doubt if the material used makes very much difference.

What is not mentioned, however, is the question of tension on the suture line. There can be no doubt that the two most important items in any anastomosis are an adequate blood supply and a freedom from tension. To make no mention of this is really to leave out one of the main causes of anastomotic leakage. I feel that this cannot be stressed too strongly and its absence really means that this article fails to make one of the most vital points which must always be borne in mind.-I am, etc.,

Oldchurch Hospital

DOUGas Park Romford, Essex

\section{Surgery for Hyperlipidaemia}

SIR,-YYour leading article discussing the use of partial ileal bypass for hyperlipidaemia (26 October, p. 180) was of particular interest in its reference to the more extensive jejunoileal bypass for gross refractory obesity. Having performed the latter procedure in a large number of patients $I$ have seen marked reduction of serum cholesterol values which have been sustained for the first two postoperative years or more, as shown in the table.

Similar reductions in serum triglyceride values have also occurred, though the number of cases studied has been smaller owing to the later availability of this measurement.

Response of 82 Patients to Treatment with Levamisole

\begin{tabular}{|c|c|c|c|c|c|c|c|c|c|c|}
\hline & & & \multicolumn{6}{|c|}{$\begin{array}{l}\text { Months after Start of } \\
\text { Levamisole Treatment }\end{array}$} & \multicolumn{2}{|c|}{$\begin{array}{l}\text { Total No. at } \\
6 \text { Months }\end{array}$} \\
\hline & & & 1 & 2 & 3 & 4 & 5 & 6 & $\mathbf{n}$ & $\%$ \\
\hline $\begin{array}{l}\text { Cured } \\
\text { Improved } \\
\text { Unchanged } \\
\text { Worse ... }\end{array}$ & $\begin{array}{l}\cdots \\
\cdots \\
\cdots\end{array}$ & $\begin{array}{l}\cdots \\
\therefore \\
\therefore\end{array}$ & $\begin{array}{r}25 \\
25 \\
28 \\
4\end{array}$ & $\begin{array}{r}28(1) \\
31(1) \\
18(1) \\
2(0)\end{array}$ & $\begin{array}{r}28(5) \\
18(6) \\
12(6) \\
7(0)\end{array}$ & $\begin{array}{c}25(13) \\
9(11) \\
10(12) \\
2(0)\end{array}$ & $\begin{array}{c}14(20) \\
11(14) \\
5(15) \\
3(0)\end{array}$ & $\begin{array}{c}12(25) \\
5(16) \\
4(18) \\
1(1)\end{array}$ & $\begin{array}{r}37 \\
21 \\
22 \\
2\end{array}$ & $\left.\begin{array}{r}45 \\
26 \\
27 \\
2\end{array}\right\} 71$ \\
\hline
\end{tabular}

Figures in parentheses indicate cumulative numbers of patients who stopped levamisole treatment because of side Figures in parentheses indicate cumulative numbers of patients who stopped levamisole treatment becaus
effects or insufficient therapeutic effect or because they considered treatment was no longer required.

\begin{tabular}{c|c|c}
\hline $\begin{array}{c}\text { Time } \\
\text { (months) }\end{array}$ & $\begin{array}{c}\text { Mean Serum Cholesterol } \\
(\mathrm{mg} / 100 \mathrm{ml})\end{array}$ & $\begin{array}{c}\text { No. of } \\
\text { Patients }\end{array}$ \\
\hline preoperation & 227.4 & 118 \\
3 & 148.9 & 96 \\
6 & 141.7 & 84 \\
12 & 136.6 & 68 \\
18 & 141.2 & 51 \\
24 & 141.5 & 29 \\
\hline
\end{tabular}

The inevitable disadvantage of partial ileal bypass is vitamin $B_{12}$ deficiency due to exclusion of the terminal ileum. This is much less frequently seen after jejunoileal bypass for obesity as $10 \mathrm{~cm}$ or more of the latter remains available for its absorption. Thus it would seem reasonable to combine the best of both operations by dividing the ileum $200 \mathrm{~cm}$ from the ileocaecal valve and anastomizing it to the terminal $10 \mathrm{~cm}$ of the ileum. There would be much less risk of the initial liver changes which are seen to a varying degree in about half the patients undergoing the more radical obesity procedures, while at the same time the acceptable results indicated above would probably be achieved.-I am, etc.,

Michael BADDELEY

The General Hospital, Birmingham

\section{Distribution and Supervision of Oral Contraceptives}

SIR,-Dr. N. A. Chisholm says (2 November, p. 287) that if nurses are to prescribe oral contraceptives as well as doctors "let it be on their own responsibility and answerable to their own professional disciplinary bodies and not on that of covering doctors."

I agree, and said so at the recent Family Planning Association national conference in London. Such a move would not be difficult to achieve. All that is necessary is a statutory instrument which could specify the circumstances in which state registered nurses could assume responsibility for prescribing. The Secretary of State made the point when she opened the conference that her department was looking into this suggestion of nurses prescribing oral contraceptives.

Having said that, however, I must recall the words of health visitor Mrs. June Clark in her address to the same conference. She said it was a myth that doctors can professionally direct and legally take responsibility for a nurse's actions. "A nurse is responsible for her own actions. Apart from the instance of prescribing drugs, there is no law which lays down what a nurse or a doctor can or cannot do, but certain safeguards must be followed."-I am, etc.,

Michael SMITH

London W.1 Chief Medical Officer,

\section{E.B. Virus and Treatment of Lymphomas}

SIR,-In their letter (23 November, p. 466) Dr. G. de Thé and his colleagues give an outline of the present knowledge of the E.B. virus. This, I would submit, is not strictly relevant to the question of using the E.B. virus as an adjunct in the treatment of lymphomas. If I had the misfortune to suffer from a finally drug-resistant generalized lymphosarcomatosis I am sure I would not really be interested in what happens to lymphocytes in cell cultures, nor in the fact that the 